\title{
ISOTOPIC VIEW OF VEGETATION AND CARBONAND NITROGEN CYCLES IN A CERRADO ECOSYSTEM, SOUTHEASTERN BRAZIL
}

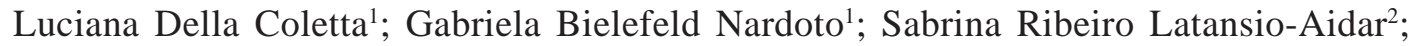
Humberto Ribeiro da Rocha3; Marcos Pereira Marinho Aidar²; Jean Pierre Henry Balbaud Ometto $^{1,4 *}$

${ }^{1}$ USP/CENA - Lab. de Ecologia Isotópica, C.P. 96 - 13400-970 - Piracicaba, SP - Brasil.

${ }^{2}$ IBt/SMA - Instituto de Botânica - Secretária do Meio Ambiente C.P. 3005 - 01061-970 - São Paulo, SP Brasil.

${ }^{3}$ USP/IAG - Depto. de Ciências Atmosféricas, R. do Matão, 1226 - Cidade Universitária - 05508-900 - São Paulo - SP, Brasil

${ }^{4}$ CCST/INPE - Av. dos Astronautas, 1.758, Jd. Granja - 12227-010 - São José dos Campos - SP, Brasil.

*Corresponding author <jpometto@igbp.inpe.br>

ABSTRACT: Carbon and nitrogen biogeochemical cycles in savannas are strongly regulated by the seasonal distribution of precipitation and pulses of nutrients released during the wetting of the dry soil and are critical to the dynamics of microorganisms and vegetation. The objective of this study was to investigate the spatial and temporal variability of $\mathrm{C}$ and $\mathrm{N}$ isotope ratios as indicators of the cycling of these elements in a cerrado sensu stricto area, within a protected area in a State Park in the state of São Paulo, Brazil. The foliar $\delta^{13} \mathrm{C}$ and $\delta^{15} \mathrm{~N}$ values varied from -33.6 to $-24.4 \%$ and -2.5 to $4.5 \%$, respectively. The $\delta^{13} \mathrm{C}$ values showed a consistent relationship with canopy height, revealing the importance of structure of the canopy over the $\mathrm{C}$ isotopic signature of the vegetation. Carbon isotopic variations associated with the length of the dry season indicated the importance of recent fixed $\mathrm{C}$ to the integrated isotopic signature of the leaf organic C. The studied Cerrado species showed a depleted foliar $\delta^{15} \mathrm{~N}$, but a wide range of foliar Nitrogen with no difference among canopy heights. However, seasonal variability was observed, with foliar $\delta^{15} \mathrm{~N}$ values being higher in the transition period between dry and rainy seasons. The variation of the foliar $\mathrm{C}$ and $\mathrm{N}$ isotope ratios presented here was consistent with highly diverse vegetation with high energy available but low availability of water and $\mathrm{N}$.

Key words: cerrado, carbon, nitrogen, stable isotopes, woody savanna

\section{VISÃO ISOTÓPICADA VEGETAÇÃOE OS CICLOS DO CARBONO E NITROGÊNIO NUM ECOSSISTEMA DE CERRADO, SUDESTE DO BRASIL}

RESUMO: Os ciclos biogeoquímicos do carbono e do nitrogênio em savanas são fortemente regulados pela distribuição sazonal de precipitação e pulsos de nutrientes liberados após eventos de chuva, que são críticos para o comportamento dos microrganismos e da vegetação. Investigou-se a variabilidade espacial e sazonal dos isótopos estáveis de C e $\mathrm{N}$ como indicadores da ciclagem destes elementos em uma área de cerrado sensu stricto de uma área protegida em um Parque Estadual no estado de São Paulo, Brasil. Os valores de $\delta^{13} \mathrm{C}$ e $\delta^{15} \mathrm{~N}$ foliar variaram de -33,6 a -24,4 \%о e -2,5 a 4,5\%, respectivamente. Os valores de $\delta^{13} \mathrm{C}$ apresentaram uma relação consistente com a altura do dossel, mostrando a importância da estrutura da vegetação na assinatura isotópica do C da vegetação. A variação isotópica do Carbono associada com a duração da estação seca indica a importância do C recentemente fixado para integrar a assinatura isotópica do C orgânico da folha. Com relação ao Nitrogênio, as espécies de Cerrado estudadas apresentaram uma grande variação no $\delta^{15} \mathrm{~N}$ foliar. Não houve relação entre o $\delta^{15} \mathrm{~N}$ foliar com a altura do dossel. No entanto, os valores de $\delta^{15} \mathrm{~N}$ foliar apresentaram uma variabilidade sazonal, com maiores valores de $\delta^{15} \mathrm{~N}$ na transição entre as estações seca e chuvosa. A variação encontrada na composição isotópica do $\mathrm{C}$ e $\mathrm{N}$ foliares foi consistente com o fato de a vegetação ser altamente diversa, tendo que lidar com uma alta disponibilidade de energia, mas baixa disponibilidade de água e $\mathrm{N}$.

Palavras-chave: cerrado, carbono, nitrogênio, isótopos estáveis, savana 


\section{INTRODUCTION}

Savanna ecosystems are primarily controlled by the interactions between water and nutrient availability, as savanna vegetation often occurs either on highly weathered soils with low nutrient availability, in regions of limited rainfall, or both (Medina, 1987). This basic environmental structure can be modified by changes in fire frequency and land-use (Bustamante et al., 2006; Miranda et al., 2002; Ratter et al., 1997).

The Brazilian Cerrado (savanna) biome covers 2 million $\mathrm{km}^{2}$ representing $23 \%$ of the area of the country. It is an ancient biome with rich biodiversity, with approximately 800 species of trees and large shrubs (Ratter et al., 1997). Despite the intense land-use conversion of the native Cerrado in the recent decades, few studies aim to understand functioning of the Cerrado ecosystem. Furthermore, studies on the influence of vegetation on carbon and nitrogen cycles in this savanna ecosystem remain scarce.

The $\mathrm{C}$ and $\mathrm{N}$ dynamics are primarily modulated by the biota, especially through photosynthesis as one of the major links between atmosphere and terrestrial ecosystems. To better understand the $\mathrm{C}$ and $\mathrm{N}$ cycles and how they affect the ecosystem functioning, it is essential to understand how plants interfere in the $\mathrm{C}$ and $\mathrm{N}$ cycle in the ecosystem. One way to address this issue is to use integrating tools such as the natural abundance of $\mathrm{C}$ and $\mathrm{N}$ isotopes. While several previous studies have focused on qualitative patterns of nitrogen stable isotope ratios $\left(\delta^{15} \mathrm{~N}\right)$ in ecosystems to derive information about the $\mathrm{N}$ cycle (Amundson et al., 2003; Bustamante et al., 2004; Martinelli et al., 1999; Ometto et al., 2006), variation in the carbon stable isotope ratios $\left(\delta^{13} \mathrm{C}\right)$ allows for making inferences about physiological plant dynamics, but also the ecophysiological aspects of the ecosystem (Ometto et al., 2006; Pataki et al., 2003).

The objective of this study was to investigate the spatial and temporal variability of $\mathrm{C}$ and $\mathrm{N}$ isotope ratios as indicators of the cycling of these elements in a cerrado sensu stricto area, in São Paulo State, southeastern Brazil.

\section{MATERIALAND METHODS}

\section{Study site}

The studied site is located in a state park in the municipality of Santa Rita do Passa Quatro (2136-38'S and $47^{\circ} 36-39^{\prime} \mathrm{W}$ ), in the State of São Paulo, Brazil. The park has 2,070 ha, with altitude varying from 590 to $740 \mathrm{~m}$. The cerrado vegetation covers $59 \%$ of the park, with the cerrado sensu stricto being the predominant phytophysiognomy (79\%) (Batalha \& Mantovani,
2001), composed of a continuous ground layer dominated by grasses and a woody layer of trees and shrubs covering $50-60 \%$ of the area, with maximum canopy height of 10m (Pivello et al., 1998). This area has been protected against fire since it was converted to a state park in 1970 (H.J. Ribeiro, personal communication). From the total Cerrado area in Brazil, about 6\% occur in the state of São Paulo, representing the southeastern boundary of the Cerrado biome; however, this remaining natural vegetation appears nowadays as small fragments of the landscape, mostly surrounded by eucalyptus, citrus and sugar cane plantations (Vieira et al., 1989).

The annual precipitation is around $1,500 \mathrm{~mm}_{\text {year }}{ }^{-1}$ (Pires Neto et al., 2005) with the dry period between May and September. The soils are predominantly Dystric Haplic Arenosol (54\%) and Eutric Haplic Arenosol (40\%) (FAO, 2006). In the studied site, the soils are predominantly dystrophic, with high sand content $(>80 \%)$, acidic $\mathrm{pH}$ values $(<4.5)$, high aluminum saturation and low cation exchange capacity (Pivello et al., 1998; Silva, 2005).

\section{Plant and Soil Sampling}

The foliar material was collected during a two-year period (from May 2005 to April 2007). A total of 180 leaf samples were collected throughout the canopy height profile, using an $18 \mathrm{~m}$ scaffold tower. For each individual plant, five to eight mature and healthy leaves were sampled from the same height. A composite sample was made with leaves sampled at the same height from the same individual plant. All sampled trees were positively identified, and the plants belonged to 22 Cerrado wood species. The plants were grouped according to the corresponding canopy height and classified as: understory ( $\leq 2 \mathrm{~m}$ ); mid canopy ( $>2 \mathrm{~m}$ and $<7 \mathrm{~m}$ ) and upper canopy ( $\geq 7 \mathrm{~m})$. Four soil samples were taken at the soil surface $(0-10 \mathrm{~cm}$ depth) near the scaffold tower mentioned above.

\section{Isotopic analyses}

All leaf samples were oven-dried at $65^{\circ} \mathrm{C}$ until constant weight and then ground to a fine powder. Soil samples were air-dried, sieved using a 2-mm mesh and homogenized. A smaller sub-sample was taken, handpicked to remove fine roots and other debris and then ground in a mortar and pestle.

A 1.5-2 mg sub-sample of ground leaf material or 15-20 mg sub-sample of ground soil were placed and sealed in a tin capsule and loaded into a ThermoQuestFinnigan Delta Plus isotope ratio mass spectrometer (Finnigan-MAT; CA, USA) in line with an Elemental Analyzer (Carlo Erba model 1110; Milan, Italy). Stable isotope ratios of $\mathrm{C}$ and $\mathrm{N}$ were measured relative to recognized international standards. Internal working 
standards (Atropine and soil standard no. 502-308 from LECO Corporation) were included in every run, as a standard laboratory procedure. Stable isotope values are reported in "delta" notation, as $\delta$ values in parts per thousand (\%), so that $\delta \%=\left(\mathrm{R}_{\text {sample }} / \mathrm{R}_{\text {standard }}\right.$ 1) $\times 1000$, where $R$ is the molar ratio of the rare to abundant isotope $\left({ }^{15} \mathrm{~N} /{ }^{14} \mathrm{~N} ;{ }^{13} \mathrm{C} /{ }^{12} \mathrm{C}\right)$ in the sample and the standard. The precision of the measurements were $\pm 0.3 \%, 0.1 \%, 0.3 \%$ and $0.5 \%$ for $\mathrm{C}, \mathrm{N}, \delta^{13} \mathrm{C}$ and $\delta^{15} \mathrm{~N}$, respectively.

\section{Statistical Analyses}

The Kolmogorov-Smirnov test was used to determine the normality of the data. As the data followed normal distribution, parametric tests and Pearson correlations were used. Student's t-test was used to assess differences between legumes and non-legumes within a site, or for seasonal comparisons both for C and $\mathrm{N}$ data. ANOVA followed by a post hoc Tukey HSD test was used to determine differences among canopy heights. All statistical analyses were performed using the software STATISTICA, version 6.1 for Windows (StatSoft, 2004). Differences at the 0.05 level were reported as significant.

\section{RESULTS}

\section{Soil characterization}

The $\mathrm{C}$ and $\mathrm{N}$ isotope ratio of the studied soil (0-10 cm depth) was $-25.7 \pm 0.9 \%$ and $4.2 \pm 0.9 \%$ (mean \pm standard deviation), respectively. The total soil $\mathrm{N}$ concentration was $0.6 \pm 0.2 \mathrm{~g} \mathrm{~kg}^{-1}$ and the $\mathrm{C}: \mathrm{N}$ ratio was $16 \pm 2.0$.

\section{Overall tendencies}

The foliar $\delta^{13} \mathrm{C}$ and $\delta^{15} \mathrm{~N}$ values varied from -33.6 to $-24.4 \%$ and -2.5 to $4.5 \%$, respectively. There were no relationships between foliar $\delta^{13} \mathrm{C}$ and $\delta^{15} \mathrm{~N}$ values $(r=-0.06)$. The species average for foliar $\delta^{13} \mathrm{C}, \delta^{15} \mathrm{~N}$, $\mathrm{N}$ concentration and C: $\mathrm{N}$ ratio are presented in Table 1.

\section{Height variability of the foliar isotope values}

Regardless of the period sampled, foliar $\delta^{13} \mathrm{C}$ values were positively correlated with canopy height $(r=0.66 ; p<0.05)$ (Figure 1) while foliar $\delta^{15} \mathrm{~N}$ values did not correlate with canopy height $(r=-0.08)$. In general, individuals belonging to the upper and middle canopy showed no differences in foliar $\delta^{13} \mathrm{C}$ averages, but a pattern of higher foliar $\delta^{13} \mathrm{C}$ could be observed for those individuals in the upper canopy (Figure 2). On the other hand, individuals in the understory showed consistently lower values of foliar $\delta^{13} \mathrm{C}$ in comparison to those of the other canopy heights $(p<0.05)$ (Figure 2). In terms of foliar $\delta^{15} \mathrm{~N}$, no differences were found among individuals from all

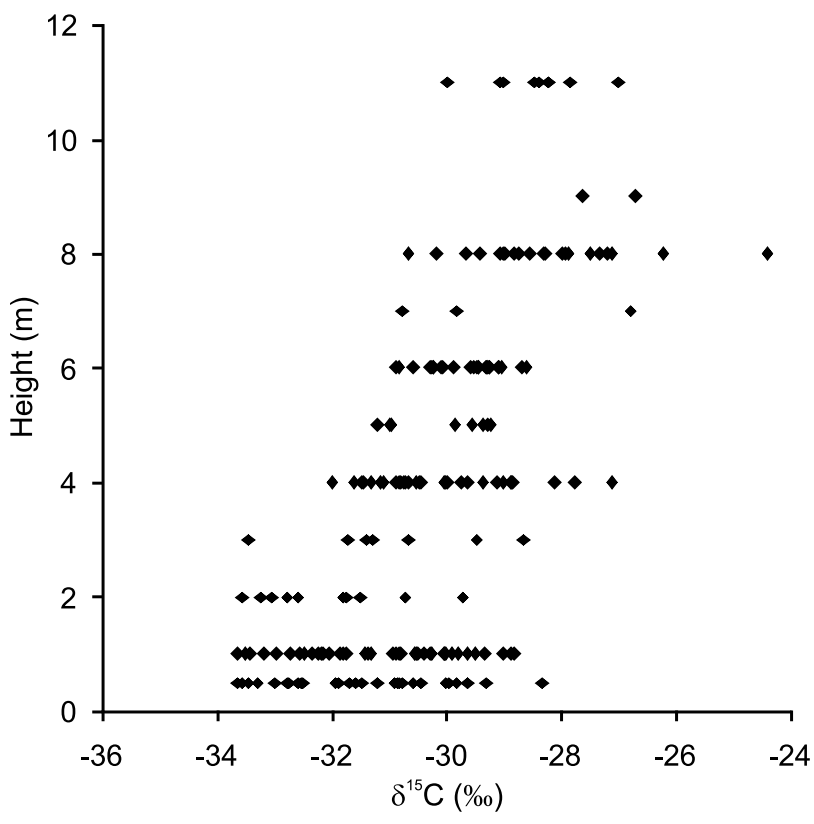

Figure 1 - Variation in the carbon isotope ratios $\left(\delta^{13} \mathrm{C}\right)$ of tree leaves according to canopy height, measured from May 2005 to April 2007.

canopy heights. Therefore, in the following sections, all the foliar $\delta^{15} \mathrm{~N}$ data include individuals from all canopy heights, unless specified.

\section{Stable isotope ratios and nitrogen content of the woody plants}

The studied species were separated according to their putative $\mathrm{N}_{2}$-fixing ability (individuals belonging to the Leguminosae family and hereafter called legumes) or inability (individuals belonging to families other than legumes and hereafter called non-legumes) (Table 1). Considering all samples, the foliar $\delta^{13} \mathrm{C}$ average values of legume leaves were higher than the non-legume leaves while mean foliar $\delta^{15} \mathrm{~N}$ values did not differ between legumes and non-legumes. However, the observed range of foliar $\delta^{15} \mathrm{~N}$ values for the legumes was notably smaller (-1.2 to $1.4 \%$ o) compared to the variation found for the non-legume species ( -2.5 to $4.5 \%$ ).

The total average foliar $\mathrm{N}$ concentration was $2.7 \pm 0.5 \%$ for legumes, which was higher than the $1.8 \pm 0.4 \%$ for the non-legume trees $(p<0.05)$. Foliar C: $\mathrm{N}$ ratio was, on the other hand, higher for the non-legume $(27.8 \pm 7.5)$ than for the legume trees $(19.8 \pm 3.5)(p<0.05)$.

Despite an absence of difference in foliar $\delta^{15} \mathrm{~N}$ between legumes and non-legumes, the legume species that had at least three individuals samples in this study were classified into two groups: potentially $\mathrm{N}_{2}$-fixing legumes and non $\mathrm{N}_{2}$-fixing legumes, according to the literature (Table 1) and were compared to two nonlegumes (Figure 3) to determine whether they were 
fixing $\mathrm{N}_{2}$ from the atmosphere. There was an overlap among the foliar $\delta^{15} \mathrm{~N}$ values of the potentially $\mathrm{N}_{2}$-fixing legumes, the non $\mathrm{N}_{2}$-fixing legumes and the nonlegumes, and it was not possible to identify their ability to fix atmospheric $\mathrm{N}$ using natural abundance of ${ }^{15} \mathrm{~N}$.

\section{Temporal variability}

The sampling strategy was devised to investigate the temporal variability of the $\delta^{13} \mathrm{C}$ and $\delta^{15} \mathrm{~N}$ values of tree leaves over a two-year period (Figure 2 and 4). When the data were classified as dry season (May to September) and rainy season (October to April), no differences were found for $\delta^{13} \mathrm{C}$ in tree leaves from all canopy heights. However, there was a tendency for the foliar $\delta^{13} \mathrm{C}$ signals of the upper and middle canopy trees to increase during the transition period between the dry and rainy seasons, which seemed to follow a one-year cycle. The lowest values occurred in the transition from the rainy to dry seasons (Figure 2). The increase of water availability in the system can poten- tially change the $\delta^{13} \mathrm{C}$ of the leaves changing the ci/ca ratio (see Farhquar et al., 1989), although the patterns observed for upper and middle canopy trees indicated a difference between the expected isotopic signature of recent assimilated $C$ and the total leaf $C$ which reflects the integrated $\mathrm{C}$ isotopic signature. For the understory species this tendency was not notable during the sampled years.

The same seasonal grouping of the data showed no differences for $\delta^{15} \mathrm{~N}$ in tree leaves, which can be related to the high variability in the foliar $\delta^{15} \mathrm{~N}$ among the studied species (Table 1). However, there was a notable response in $\delta^{15} \mathrm{~N}$ values to variations in precipitation, with higher $\delta^{15} \mathrm{~N}$ values occurring in the transition period between dry and rainy seasons and lower values occurring in the transition between rainy and dry seasons (Figure 4). This seasonal tendency was observed in both sampled years, but a variation in the magnitude on $\delta^{15} \mathrm{~N}$ values could be noted, both for legume and non-legume species.

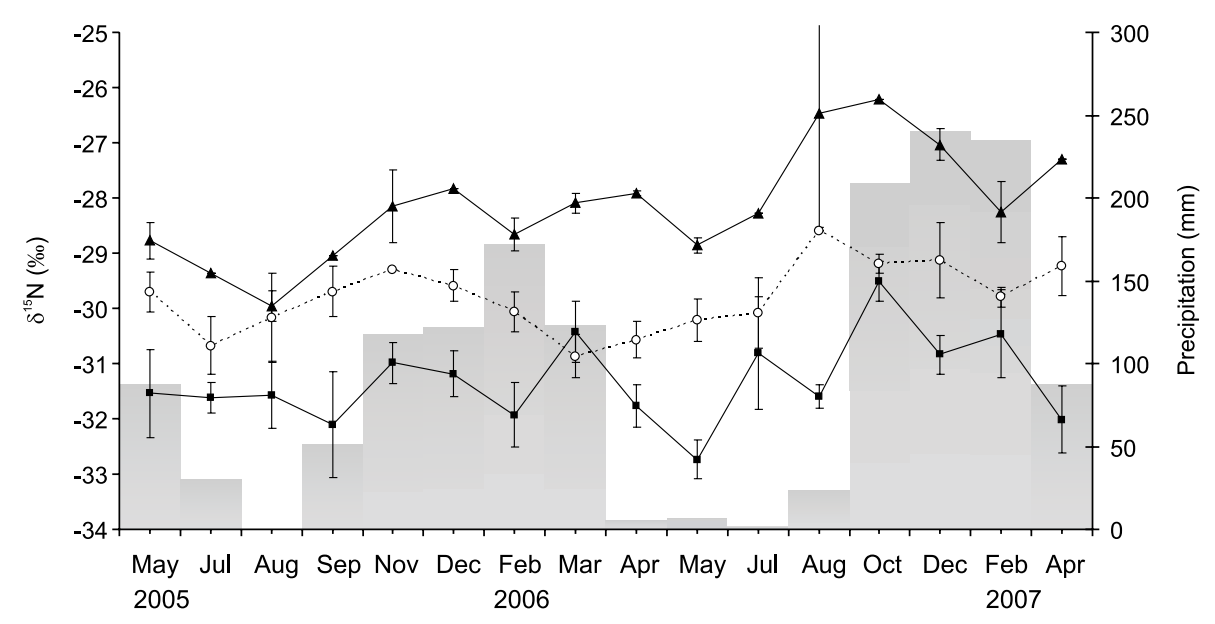

Figure 2 - Temporal variation (mean \pm standard error) in the carbon isotope ratios $\left(\delta^{13} \mathrm{C}\right)$ of tree leaves at three different heights and average monthly precipitation (gray bars) at a State Park, SP, Brazil: ( $\mathbf{\square}$ - black square) leaves collected from the understory (height $\leq 2 \mathrm{~m}$ ); ( $\mathrm{O}$ - open circle) leaves collected from the middle canopy ( $>2 \mathrm{~m}$ and $<7 \mathrm{~m})$; ( $\boldsymbol{\Delta}$ - close triangle) leaves collected from the upper canopy ( $\geq 7 \mathrm{~m}$ ).

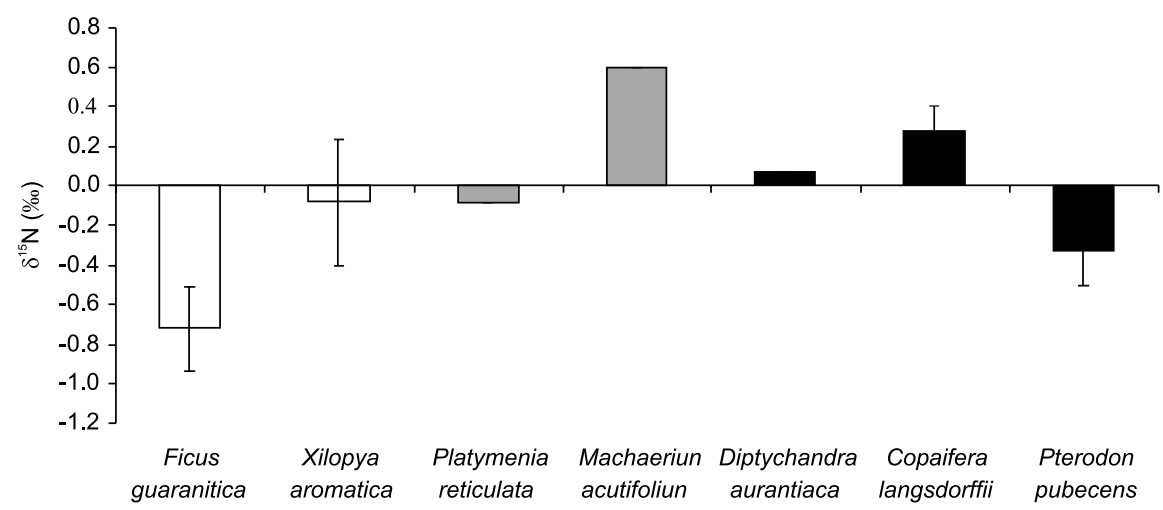

Figure 3 - Leaf nitrogen isotope ratios $\left(\delta^{15} \mathrm{~N}\right)$ (mean \pm standard error) for selected legume and non-legume species which were separated in three groups: (open bars) non-legume species, (black bars) non $\mathrm{N}_{2}$-fixing legume species and, (gray bars) potentially $\mathrm{N}_{2}-$ fixing legume species. 
Table 1 - Mean and standard deviation of $\delta^{13} \mathrm{C}$ and $\delta^{15} \mathrm{~N}$, foliar $\mathrm{N}$ concentration, and C:N ratios in leaves of Cerrado tree species classified in three canopy heights: understory, middle canopy and upper canopy.

\begin{tabular}{|c|c|c|c|c|c|c|c|}
\hline Species $^{1}$ & Family $^{2}$ & Heigh canopy & $n^{3}$ & $\delta^{13} \mathrm{C}$ & $\delta^{15} \mathrm{~N}$ & $\mathrm{C}: \mathrm{N}$ & $\mathrm{N} \%$ \\
\hline $\begin{array}{l}\text { Acosmium subelegans } \\
\text { (Mohlenb.) Yakovl. }{ }^{(+/-)}\end{array}$ & Fabaceae-Faboideae & $\begin{array}{l}\text { Under } \\
\text { Middle }\end{array}$ & $\begin{array}{l}6 \\
5\end{array}$ & $\begin{array}{l}-30.5 \pm 1.2 \\
-30.1 \pm 1.1\end{array}$ & $\begin{array}{l}-0.4 \pm 0.6 \\
-0.6 \pm 0.8\end{array}$ & $\begin{array}{l}17.1 \pm 3.0 \\
22.7 \pm 7.0\end{array}$ & $\begin{array}{l}3.0 \pm 0.4 \\
2.4 \pm 0.7\end{array}$ \\
\hline $\begin{array}{l}\text { Anadenanthera falcata } \\
\text { (Benth.) Speg. }\end{array}$ & Fabaceae-Mimosoideae & Middle & 3 & $-29.6 \pm 1.0$ & $0.4 \pm 0.9$ & $20.0 \pm 0.1$ & $2.8 \pm 0.02$ \\
\hline $\begin{array}{l}\text { Caryocar brasiliense Camb. } \\
\text { ssp. brasiliense }\end{array}$ & Caryocaraceae & Middle & 8 & $-28.9 \pm 1.1$ & $-1.5 \pm 0.6$ & $29.4 \pm 4.0$ & $1.7 \pm 0.3$ \\
\hline Copaifera langsdorffii Desf.(-) & Fabaceae-Caesalpinoideae & Upper & 26 & $-27.7 \pm 1.1$ & $0.3 \pm 0.6$ & $22.1 \pm 3.2$ & $2.4 \pm 0.4$ \\
\hline Dimorphandra mollis Benth..$^{(+)}$ & Fabaceae-Caesalpinoideae & Upper & 9 & $-29.4 \pm 1.5$ & $-0.02 \pm 0.5$ & $17.0 \pm 2.9$ & $3.1 \pm 0.7$ \\
\hline $\begin{array}{l}\text { Diptychandra aurantiaca Tul. } \\
\text { ssp. Aurantiaca }\end{array}$ & Fabaceae-Caesalpinoideae & Middle & 1 & -31.7 & 0.1 & 19.4 & 2.7 \\
\hline Ficus guaranitica Chodat & Moraceae & Middle & 18 & $-30.6 \pm 0.6$ & $-0.7 \pm 0.8$ & $30.1 \pm 6.4$ & $1.8 \pm 0.5$ \\
\hline Lafoensia pacari St. Hil. & Lythraceae & Under & 1 & -31.3 & -0.5 & 25.2 & 1.9 \\
\hline $\begin{array}{l}\text { Machaerium acutifolium } \\
\text { Vog. }^{(+)}\end{array}$ & Fabaceae-Faboideae & Middle & 1 & -30.5 & 0.6 & 15.3 & 3.4 \\
\hline Miconia stenostachya DC. & Melastomataceae & Under & 9 & $-31.2 \pm 0.7$ & $0.6 \pm 0.5$ & $23.3 \pm 2.2$ & $2.1 \pm 0.2$ \\
\hline Myrcia guianensis DC. & Myrtaceae & Under & 4 & $-32.6 \pm 1.3$ & $-0.2 \pm 0.9$ & $34.2 \pm 5.0$ & $1.4 \pm 0.2$ \\
\hline Myrcia lingua Berg & Myrtaceae & Under & 15 & $-32.4 \pm 1.1$ & $-0.9 \pm 0.9$ & $33.7 \pm 5.2$ & $1.4 \pm 0.2$ \\
\hline Plathymenia reticulata Benth. & Fabaceae-Faboideae & Under & 1 & -30.8 & -0.1 & 21.2 & 2.4 \\
\hline $\begin{array}{l}\text { Protium heptaphyllum (Aubl.) } \\
\text { March. ssp. heptaphyllum }\end{array}$ & Burseraceae & Under & 1 & -30.9 & 1.9 & 27.5 & 1.7 \\
\hline $\begin{array}{l}\text { Pterodon pubescens (Benth.) } \\
\text { Benth. }{ }^{(-)}\end{array}$ & Fabaceae-Faboideae & Upper & 6 & $-29.5 \pm 0.8$ & $-0.3 \pm 0.4$ & $21.7 \pm 3.8$ & $2.5 \pm 0.4$ \\
\hline Qualea multiflora Mart. & Vochysiaceae & $\begin{array}{l}\text { Under } \\
\text { Middle }\end{array}$ & $\begin{array}{l}4 \\
5\end{array}$ & $\begin{array}{l}-30.6 \pm 0.5 \\
-30.6 \pm 0.8\end{array}$ & $\begin{array}{l}-0.6 \pm 0.4 \\
-0.5 \pm 0.6\end{array}$ & $\begin{array}{l}18.8 \pm 2.6 \\
22.7 \pm 2.4\end{array}$ & $\begin{array}{l}2.4 \pm 0.3 \\
2.0 \pm 0.2\end{array}$ \\
\hline Rollinia sericea R. E. Fries. & Annonaceae & Under & 1 & -31.2 & 4.5 & 25.9 & 2.0 \\
\hline Roupala montana Aubl. & Proteaceae & Under & 10 & $-32.5 \pm 0.7$ & $3.4 \pm 0.7$ & $38.8 \pm 6.0$ & $1.3 \pm 0.2$ \\
\hline $\begin{array}{l}\text { Schefflera vinosa (Cham. \& } \\
\text { Schltdl.) Frodin. }\end{array}$ & Araliaceae & Under & 4 & $-29.5 \pm 1.0$ & $0.5 \pm 0.3$ & $22.8 \pm 2.6$ & $2.3 \pm 0.3$ \\
\hline Styrax cf pohlii A. DC. & Styracaceae & Under & 1 & -31.6 & -2.5 & 33.9 & 1.5 \\
\hline $\begin{array}{l}\text { Tocoyena formosa (Cham. \& } \\
\text { Schlecht.) K. Schum }\end{array}$ & Rubiaceae & Middle & 2 & $-29.1 \pm 0.3$ & $-0.6 \pm 0.1$ & $39.3 \pm 7.5$ & $1.3 \pm 0.3$ \\
\hline $\begin{array}{l}\text { Xylopia aromatica (Lam.) } \\
\text { Mart. }\end{array}$ & Annonaceae & $\begin{array}{l}\text { Under } \\
\text { Middle } \\
\text { Upper }\end{array}$ & $\begin{array}{c}13 \\
13 \\
3\end{array}$ & $\begin{array}{l}-31.5 \pm 1.2 \\
-29.8 \pm 0.6 \\
-29.0 \pm 0.8\end{array}$ & $\begin{array}{r}0.02 \pm 0.9 \\
-0.1 \pm 1.2 \\
0.2 \pm 0.1\end{array}$ & $\begin{array}{l}21.9 \pm 2.3 \\
22.0 \pm 2.4 \\
19.8 \pm 1.7\end{array}$ & $\begin{array}{l}2.3 \pm 0.3 \\
2.3 \pm 0.2 \\
2.6 \pm 0.2\end{array}$ \\
\hline
\end{tabular}

${ }^{1}$ Classification of nodulation capacity for the genus according to the literature: $(+)$ proven or probable capacity, (+/-) some genus nodulate and some not, (-) probably incapable of nodulating. Data from Allen \& Allen (1981); Faria et al. (1989); Faria \& Lima (1998); ${ }^{2}$ Classification according to Souza \& Lorenzi (2005). ““ $n$ ” represents the individuals numbers divided by each height canopy.

\section{DISCUSSION}

The data presented here indicate a high variability of the foliar $\delta^{13} \mathrm{C}$ among the Cerrado species but strongly associated with canopy height. The overall average $\delta^{13} \mathrm{C}$ value for all leaf samples $(-30.2 \pm 1.8 \%$; $\mathrm{n}=180)$ (mean $\pm 1 \mathrm{SD}$ ) was higher than the average values reported for tropical rainforests (Bonal et al., 2000; Buchmann et al., 1997; Ometto et al., 2006). Medina \& Minchin (1980) and Ometto et al. (2006) showed a significant $C$ isotopic variation in relation to the pho- tosynthetically active radiation (PAR) between the upper and lower part of an Amazonian terra-firme forests, named the "canopy effect". For the dense canopy of the Amazonian terra-firme forests, for example, plants located in lower canopy strata had a different distribution and quantity of stomata, compared to the upper canopy leaves.

The lower incidence of direct radiation and possible low atmospheric water vapor deficit (VPD), associated with greater stability of the microclimate in this section of the canopy, allows the understory plants to 


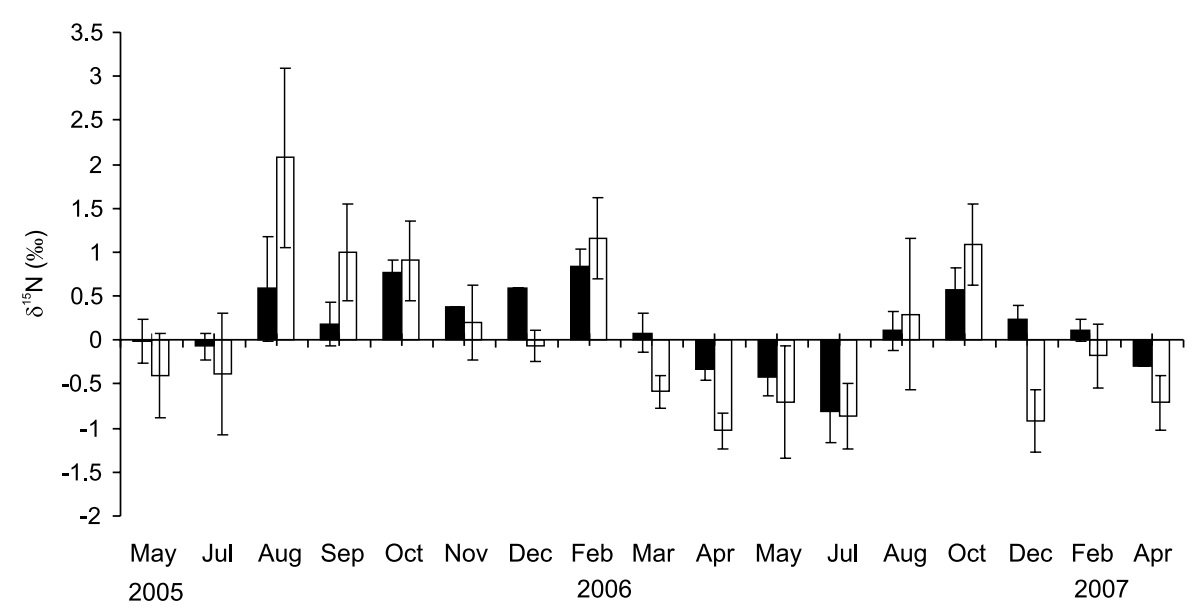

Figure 4 - Temporal variation in the nitrogen isotope ratios $\left(\delta^{15} \mathrm{~N}\right)$ of tree leaves (mean \pm standard deviation), and the data were separated in two groups of plants: (black bars) legume and, (open bars) non-legume individuals.

maintain their stomata open for longer periods (Ometto et al., 2002; Ometto et al., 2006). Hence, leaves in the upper part of the canopy strata discriminate less in regards to carbon 13 , reflecting in heavier $\delta^{13} \mathrm{C}$ values. In this study, the differences in the $\delta^{13} \mathrm{C}$ values found for the canopy strata suggest different strategies of plants for assimilating $\mathrm{CO}_{2}$, as also observed by Ehleringer et al. (1993). As briefly mentioned above, the response of photosynthesis to precipitation or water availability will be reflected in the carbon isotope ratios of the vegetation (Farquhar et al., 1989). The C isotope ratios of foliar tissue represent a balance between stomatal conductance to supply $\mathrm{CO}_{2}$ and photosynthetic demand consuming $\mathrm{CO}_{2}$, integrated in the ci/ca ratio. In the Brazilian Cerrado, little data on the $\mathrm{C}$ isotopic variation has been published. Mattos et al. (1997), looking at the $\delta^{13} \mathrm{C}$ of 13 species from 11 families, in a Cerrado area near this study area (São Carlos, SP) calculated the intrinsic water use efficiency and identified limitations to carbon fixation caused by water stress.

The strong seasonality observed in precipitation and water availability was not clearly shown in our $\delta^{13} \mathrm{C}$ values, although, in the upper canopy strata, plants seem to be more sensitive to variation in water availability. In the Amazonian terra-firme forests the seasonal distribution of precipitation is correlated with the $\delta^{13} \mathrm{C}$ variability of tree leaves (Ometto et al., 2006). Their observations suggested a time lag between the C structurally allocated on the leaves' tissues and the C fixed by photosynthesis, being correlated, therefore, with previous rainfall. In general, a trend indicating a lighter $\delta^{13} \mathrm{C}$ signal with an increase of water availability and ci/ca ratio is typically observed (Walcroft et al., 1997). Some authors working in the Amazonian terra-firme forests with gas flux studies (eddy-covariance) and biomass measurements observed small wood increments during the dry season, whereas a significant increase was observed just before the start of the rainy season (Goulden et al., 2004; Saleska et al., 2003), which could indicate a lighter isotope signal of $\mathrm{C}$ fixed at the beginning of the rainy season. The mechanism suggested by Saleska et al. (2003) for the increase of diameter wood increment immediately preceding the return of the rain could be related to the specific $\mathrm{C}$ re-allocation by the plant.

The higher foliar $\delta^{13} \mathrm{C}$ of middle and upper canopy during the dry season might reflect the cerrado sensu stricto canopy structure, straining this vegetation in a higher VDP atmosphere and the lower water availability, typical of the season. The range of the foliar $\delta^{13} \mathrm{C}$ data of the lower canopy individuals is similar to the lower canopy $\delta^{13} \mathrm{C}$ data of the Amazonian terra-firme forests throughout the year. This seems to reflect an adaptation of the species located in this stratum to a more stable micro-climate, discriminating against the heavier carbon $\left({ }^{13} \mathrm{C}\right)$, therefore reflecting a higher relationship between stomata conductance and photosynthetic capacity.

Variations in $\delta^{13} \mathrm{C}$ values have been correlated with other parameters not directly related to canopy height, including water-use efficiency (Bonal et al., 2000; Guehl et al., 1998), branch morphology and hydraulic conductivity (Panek, 1996), structural and compositional differences between leaves (Bonal et al., 2000; Broadmeadow \& Griffiths, 1993), and leaf age and position in the crown (Gebauer \& Schulze, 1991). However, the relative contribution of these factors to variations in $\delta^{13} \mathrm{C}$ of plant tissue remains unknown.

Plant species in the studied cerrado sensu stricto area showed depleted foliar $\delta^{15} \mathrm{~N}$ signatures, and there was no difference between canopy heights. However, the range of foliar $\delta^{15} \mathrm{~N}$ was similar to the wide variation in foliar $\delta^{15} \mathrm{~N}$ reported by Bustamante et al. (2004) in 
different areas of cerrado sensu stricto in Central Brazil. On the other hand, data from Brazilian forest ecosystems have consistently higher foliar $\delta^{15} \mathrm{~N}$ with a narrow range of values compared to the Cerrado data (Aidar et al., 2003; Ometto et al., 2006).

Several factors contribute to the large variability in foliar $\delta^{15} \mathrm{~N}$ in the Cerrado, including associations with mycorrhizal fungi, the variability in the levels of $\delta^{15} \mathrm{~N}$ in the soil organic matter according to depth, the seasonality of $\mathrm{N}$-immobilization and $\mathrm{N}$ mineralization (Bustamante et al., 2004). Despite the large foliar $\delta^{15} \mathrm{~N}$ variability among the Cerrado trees, seasonal variability was observed in the $\mathrm{N}$ isotopic composition of the Cerrado plant leaves, with foliar $\delta^{15} \mathrm{~N}$ values increasing during the transition period from the dry to the rainy seasons. Some factors may contribute to the seasonal pattern found, as discussed in detail by Bustamante et al. (2004), including the fact that older tissues tend to have been higher $\delta^{15} \mathrm{~N}$ than younger ones due to the translocation of $\mathrm{N}$, suggesting that the net isotopic effect of the phenological cycle in the Cerrado would lead to be higher $\delta^{15} \mathrm{~N}$ values during the dry season. Whole-plant and leaf $\mathrm{N}$ isotope composition are determined both by the isotope ratio of the external $\mathrm{N}$ source and physiological mechanisms within the plant; however, whole-plant $\mathrm{N}$ isotope composition can reflect that of the $\mathrm{N}$ source when plant demand exceeds $\mathrm{N}$ supply (Evans, 2001).

In the cerrado sensu stricto, although net $\mathrm{N}$ mineralization and net nitrification rates are higher during the rainy season, inorganic- $\mathrm{N}$ concentrations decrease during the rainy season, indicating that plant uptake decreases inorganic- $\mathrm{N}$ stocks and consumes the $\mathrm{N}$ released from net mineralization (Nardoto \& Bustamante, 2003). Despite the transient nature of nitrate in soils, the low content of $\mathrm{NO}_{3}-\mathrm{N}$ in soils of the Cerrado sites could be related to low nitrification rates, even though significant production of $\mathrm{NH}_{4}-\mathrm{N}$ occurs.

The rate of net $\mathrm{N}$ mineralization in a cerrado sensu stricto area in Central Brazil protected from fire for 28 years was only $14.7 \mathrm{~kg} \mathrm{~N} \mathrm{ha}^{-1} \mathrm{yr}^{-1}$ and $\mathrm{NO}_{3}-\mathrm{N}$ accumulation occurred only in short periods during the rainy season (Nardoto \& Bustamante, 2003). In addition, the high C:N of litter (>50:1) may contribute to the low rates of decomposition and mineralization in Cerrado areas, thus maintaining low availability of $\mathrm{N}$ in this ecosystem (Bustamante et al., 2006).

Mechanistic explanations for local or regional patterns of $\delta^{15} \mathrm{~N}$ values would require the use of Rayleigh equations to determine variations in the product (e.g. plants) and the source (e.g. nitrogen) (Robinson, 2001). This equation establishes the relationship between the isotopic composition of precursor and product based on the fractionation factor and change in concentration of the substrate. Although, according to Högberg (1997), the complexity of $\mathrm{N}$ dynamics in the plant-soil system renders it quite difficult to apply a source-product isotopic model. Nonetheless, analysis of the ${ }^{15} \mathrm{~N}$ natural abundance can provide information on sources and transformations of $\mathrm{N}$ in ecosystems (Amundson et al., 2003; Högberg, 1997; Martinelli et al., 1999; Roggy et al., 1999), since variations in $\delta^{15} \mathrm{~N}$ reflect $\mathrm{N}$ isotope fractionations where, for a given reaction, the product typically becomes ${ }^{15} \mathrm{~N}$ depleted relative to the substrate (Högberg, 1997).

We did not measure the isotopic composition of soil nitrate; however, there is significant fractionation during the nitrification process, depositing in the soil, isotopically depleted nitrate as compared to the ammonium (Högberg, 1997). Consequently, nitrate uptake during the rainy season would result in plants with lower $\delta^{15} \mathrm{~N}$ values in comparison to the dry season when ammonium predominates in the cerrado sensu stricto soil (Nardoto \& Bustamante, 2003). Therefore, isotopically identifying the $\mathrm{N}$ source of Cerrado woody plants remain an open prospect.

Högberg (1997) predicted that if plants derived a substantial portion of $\mathrm{N}$ inputs from atmospheric $\mathrm{N}_{2}$, then leaf $\delta^{15} \mathrm{~N}$ values would be approximately $0-2 \%$. The $\delta^{15} \mathrm{~N}$ method might be inadequate for estimating $\mathrm{N}_{2}$ fixation in such $\mathrm{N}$-limited conditions where plants tend to be depleted in ${ }^{15} \mathrm{~N}$ as observed in the Cerrado plants because the foliar $\delta^{15} \mathrm{~N}$ values of the legumes overlapped with those of the non-legumes. Nonetheless, nitrogen biological fixation is considered an important process for delivering $\mathrm{N}$ to the system, especially since this element is limited and there is enough light to induce biological fixation. Gehring et al. (2005) considered significant symbiotic biological nitrogen fixation (symbiotic BNF) in secondary regrowth (where N-limiting conditions tend to be higher) contrary to low symbiotic BNF in mature rainforest in Central Amazon. Given that areas with N-limited conditions such as the cerrado sensu stricto studied herein, the role of symbiotic BNF is supposedly an important $\mathrm{N}$ input to the system.

Bustamante et al. (2006) suggest that most Cerrado legumes, particularly those of the subfamily Faboideae, are active $\mathrm{N}_{2}$-fixers under natural conditions, but for a reliable assessment of the contribution of legumes to the $\mathrm{N}$ budget of savannas, it is necessary to understand controls over legume density and seasonal nitrogen fixation activity. However, regardless of whether they are active $\mathrm{N}_{2}$-fixers or not, the studied legume species showed consistently higher foliar $\mathrm{N}$ concentration than the non-legume. This same overall trend has been observed for other Cerrado areas (Bustamante et al., 2004; Sprent et al., 1996), and tropical rainforests 
(Ometto et al., 2006; Roggy et al., 1999; Vitousek et al., 2002), which may be related to a more efficient $\mathrm{N}$ assimilation process in legumes with a high-N-demanding character (McKey, 1994).

The difference in canopy structures is an important factor in the ecological understanding of the system, and the $\delta^{13} \mathrm{C}$ values obtained in this study showed a consistent response, changing its value according to canopy height, reflecting the non-homogeneous cerrado sensu stricto structure. The seasonal variability of rainfall indicates the importance of recent fixed $\mathrm{C}$ to the integrated isotopic signature of the leaf organic $\mathrm{C}$ and, concerning the $\mathrm{N}$ dynamics in the ecosystem, the seasonality of water availability seems to play a major role in the plant uptake pattern of $\mathrm{N}$. Therefore, the variation of the foliar $\mathrm{C}$ and $\mathrm{N}$ isotope ratios presented here was reliable for highly diverse vegetation having high energy but low availability of water and nitrogen.

\section{ACKNOWLEDGEMENTS}

To H.J. Ribeiro, director of the Parque Estadual de Vassununga and the Instituto Florestal (SMA-SP) for the logistical support of this work; Dr. M.Z Moreira, M.A. Perez and F. Fracassi (CENA/USP) for the technical lab support; E. Mazzi, J. Bitencourt and M. Scaranello (CENA/USP) for their contributions in the field, and J.T. Tatsch for the precipitation data (IAG/ USP). We are grateful to Ana Cláudia Oliveira (ESALQ/ USP) for her valuable help with plant identification. Luciana Della Coletta had fellowship from FAPESP. This study was supported by grant from the project "Interação Biosfera-Atmosfera Fase II - Cerrados e Mudanças no Uso da Terra - BIOTA/FAPESP”.

\section{REFERENCES}

AIDAR, M.P.M.; SCHIMIDT, S.; MOSS, G.; STEWART, G.R.; JOLY, C.A. Nitrogen use estrategies of neotropical rainforest trees in threatened Atlantic Forest. Plant Cell and Environment, v.26, p.389-399, 2003.

ALLEN, O.N.; ALLEN, E.K. The leguminosae: a source book of characteristic, uses, and nodulation. Madison: University of Wisconsin Press, 1981. 811p.

AMUNDSON, R.; AUSTIN, A.T.; SCHUUR, E.A.G.; YOO, K.; MATZEK, V.; KENDALL, C.; UEBERSAX, A.; BRENNER, D.; BAISDEN, W.T. Global patterns of the isotopic composition of soil and plant nitrogen. Global Biogeochemical Cycles, v.17, p.1031, 2003.

BATALHA, M.A.; MANTOVANI, W. Reproductive phenological patterns of Cerrado plant species at the Pé-de-Gigante Reserve (Santa Rita do Passa Quatro, SP, Brasil): a comparison between the herbaceous and woody flora. Revista Brasileira de Biologia, v.60, p.129-145, 2001.

BONAL, D.; SABATIER, D.; MONTPIED, P.; TREMEAUX, D.; GUEHL, J.M. Interspecific variability of $\delta^{13} \mathrm{C}$ among trees in rainforests of French Guiana: functional groups and canopy integration. Oecologia, v.124, p.454-468, 2000.
BROADMEADOW, M.S.J.; GRIFFITHS, H. Carbon isotope discrimination and the coupling of $\mathrm{CO}_{2}$ fluxes within forest canopies. In: EHLERINGER, J.R.; HALL, A.E.; FARQUHAR G.D. (Ed.) Stable isotopes and plant carbon-water relations. San Diego: Academic Press, 1993. p.109-130.

BUCHMANN, N.; GUEHL, J.M.; BARIGAH, T.S.; EHLERINGER, J.R. Interseasonal comparison of $\mathrm{CO}_{2}$ concentrations, isotopic composition and carbon dynamics in an Amazonian rainforest (French Guiana). Oecologia, v.110, p.120-131, 1997.

BUSTAMANTE, M.M.C.; MARTINELLI, L.A.; SILVA, D.A.; CAMARGO, P.B.; KLINK, C.A.; DOMINGUES, T.F.; SANTOS, R.V. N-15 natural abundance in woody plants and soils of central Brazilian savannas (Cerrado). Ecological Applications, v.14, p.200-213, 2004.

BUSTAMANTE, M.M.C.; MEDINA, E.; ASNER, G.P.; NARDOTO, G.B.; GARCIA-MONTIEL, D.C. Nitrogen cycling in tropical and temperate savannas. Biogeochemistry, v.79, p.209-237, 2006.

EHLERINGER, J.R.; HALL, A.E.; FARQUHAR, G.D. Stable isotopes and plant carbon: water relations. London: Academic Press, 1993. 555p.

EVANS, R.D. Physiological mechanisms influencing plant nitrogen isotope composition. Trends in Plant Science, v.6, p.121126, 2001.

FAO. World reference base for soil resources. FAO/ISSS/ISRIC, Rome: FAO/ISSS/ISRIC, 2006. 145p. (FAO World Soil Resources Reports, 84).

FARIA, S.M.; LEWIS, G.P.; SPRENT, J.I.; SUTHERLAND, J.M. Ocurrence of nodulation in the Leguminosae. New Phytologist, v.111, p.607-619, 1989.

FARIA, S.M.; LIMA, H.C. Additional studies of the nodulation status of legume species in Brazil. Plant and Soil, v.200, p.185192, 1998.

FARQUHAR, G.D.; EHLERINGER, J.R.; HUBICK, K.T. Carbon isotope discrimination and Photosynthesis. Annual Review of Plant Physiology and Plant Molecular Biology, v.40, p.503-537, 1989.

GEBAUER, G.; SCHULZE, E.D. Carbon and nitrogen isotope ratios in different compartments of a healthy and a declining piceaabies forest in the fichtelgebirge, NE Bavaria. Oecologia, v.87, p.198-207, 1991

GEHRING, C.; VLEK, P.L.G.; DE SOUZA, L.A.G.; DENICH, M. Biological nitrogen fixation in secondary regrowth and mature rainforest of central Amazonia. Agriculture Ecosystems \& Environment, v.111, p.237-252, 2005.

GOULDEN, M.L.; MILLER, S.D.; ROCHA, H.R.; MENTON, M.C.; FREITAS, H.C.; FIGUEIRA, A.M.S.; SOUZA C.A.D. Diel and seasonal patterns of tropical forest $\mathrm{CO}_{2}$ exchange. Ecological Applications, v.14, p.S42-S54, 2004.

GUEHL, J.M.; DOMENACH, A.M.; BEREAU, M.; BARIGAH, T.S.; CASABIANCA, H.; FERHI, A.; GARBAYE, J. Functional diversity in an Amazonian rainforest of French Guyana: a dual isotope approach $\left(\delta^{15} \mathrm{~N}\right.$ and $\left.\delta^{13} \mathrm{C}\right)$. Oecologia, v.116, p.316330, 1998.

HÖGBERG, P. N-15 natural abundance in soil-plant system. New Phytologist, v.137, p.179-203, 1997.

MARTINELLI, L.A.; PICCOLO, M.C.; TOWNSEND, A.R.; VITOUSEK, P.M.; CUEVAS, E.; MCDOWELL, W.H.; ROBERTSON, G.P.; SANTOS, O.C.; TRESEDER, K. Nitrogen stable isotopic composition of leaves and soil: tropical versus temperate forests. Biogeochemistsry, v.46, p.45-65, 1999.

MATTOS, E.A.; REINERT, F.; MORAES, J.A.P.V. Comparison of carbon isotope discrimination and $\mathrm{CO}_{2}$ and $\mathrm{H}_{2} \mathrm{O}$ gas exchanged between the dry and the wet season in leaves of several Cerrado woody species. Revista Brasileira de Fisiologia Vegetal, v.9, p.77-82, 1997.

McKEY, D. Legumes and nitrogen: the evolutionary ecology of a nitrogen-demanding lifestyle. In: SPRENT, J.M.; McKEY, D. (Ed.) Advances in legume systematics: the nitrogen factor. Kew: Royal Botanic Gardens, 1994. p.211-228. 
MEDINA, E.; MINCHIN, P. Stratification of $\delta^{13} \mathrm{C}$ values of leaves in Amazonian rainforests. Oecologia, v.45, p.355-378, 1980.

MEDINA, E. Nutrients: requirements, conservation and cycles of nutrients in the herbaceous layer. In: WALTER, B.H. (Ed.) Determinants of tropical savannas. Paris: IUBS, 1987. p.3966.

MIRANDA, H.S.; BUSTAMANTE, M.M.C.; MIRANDA, A.C. The ûre factor. In: OLIVEIRA, P.S.; MARQUIS, R.J. (Ed.) The Cerrados of Brazil: ecology and natural history of a neotropical savanna. New York: Columbia University Press, 2002. p.51-68.

NARDOTO, G.B.; BUSTAMANTE, M.M.C. Effects of fire on soil nitrogen dynamics and microbial biomass in savannas of Central Brazil. Pesquisa Agropecuária Brasileira, v.38, p.955-962, 2003.

OMETTO, J.P.H.B.; FLANAGAN, L.; MARTINELLI, L.A.; MOREIRA, M.Z.; HIGUCHI, N.; EHLERINGER, J.R. Carbon isotope discrimination in forest and pasture ecosystems of the Amazon Basin, Brazil. Global Biogeochemical Cycles, Washington, v. 16, p.1109, 2002.

OMETTO, J.P.H.B.; EHLERINGER, J.R.; DOMINGUES, T.F.; BERRY, J.A.; ISHIDA, F.Y.; MAZZI, E.; HIGUCHI, N.; FLANAGAN, L.B.; NARDOTO, G.B.; MARTINELLI, L.A. The stable carbon and nitrogen isotopic composition of vegetation in tropical forests of the Amazon Basin, Brazil. Biogeochemistry, v.79, p.251-274, 2006.

PATAKI, D.E.; EHLERINGER, J.R.; FLANAGAN, L.B.; YAKIR, D.; BOWLING, D.R.; STILL, C.J.; BUCHMANN, N; KAPLAN, J.O.; BERRY, J.A. The application and interpretation of Keeling plots in terrestrial carbon cycle research. Global Biogeochemical Cycles, v.17, p.1022, 2003.

PANEK, J.A. Correlations between stable carbon-isotope abundance and hydraulic conductivity in Douglas-fir across a climate gradient in Oregon, USA. Tree Physiology, v.16, p.747-755, 1996.

PIRES NETO, A.G.; ROCHA, H.R.; COOPER, M.; SHIDA, C.N. Caracterização física do Cerrado Pé-de-Gigante e uso das terras na região: Fisiografia da região. In: PIVELLO, V.R. \& VARANDA, E.M. (Orgs.) O cerrado do Pé-de-Gigante, Parque Estadual de Vassununga: ecologia e conservação. São Paulo: SMA. 2005. 312p.

PIVELLO, V.R.; BITENCOURT, M.D.; MANTOVANI, W.; MESQUITA, H.N.; BATALHA, M.A.; SHIDA, C. Proposta de zoneamento ecológico para a Reserva de Cerrado Pé-de-Gigante (Santa Rita do Passa Quatro, SP). Revista Brasileira de Ecologia, v.2, p.108-118, 1998.
RATTER, J.A.; RIBEIRO, J.F.; BRIDGEWATER, S. The Brazilian Cerrado vegetation and threats to its biodiversity. Annals of Botany, v.80, p.223-230, 1997.

ROBINSON, D. $\delta^{15} \mathrm{~N}$ as an integrator of the nitrogen cycle. Trends in Ecology \& Evolution, v.16, p.153-162, 2001.

ROGGY, J.C.; PREÂVOST, M.F.; GARBAYE, J.; DOMENACH, A.M. Nitrogen cycling in the tropical rain forest of French Guiana: comparison of two sites with contrasting soil types using $\delta^{15} \mathrm{~N}$. Journal of Tropical Ecology, v.15, p.1-22, 1999.

SALESKA, S.R.; MILLER, S.; MATROSS, D.; GOULDEN, M.; WOFSY, S.; ROCHA, H.; CAMARGO, P.; CRILL, P.; DAUBE, B.; FREITAS, H.; HUTYRA, L.; KELLER, M.; KIRCHOFF, V.; MENTON, M.; MUNGER, J.; PYLE, E.; RICE, A.; SILVA, H. Carbon in Amazon forests: unexpected seasonal fluxes and disturbance-induced losses. Science, v.302, p.1554-1557, 2003.

SILVA, D.M.L. Dinâmica de nitrogênio em microbacias no Estado de São Paulo: 2005. Piracicaba: USP/CENA, 2005. 106p. Tese (Doutorado).

SOUZA, V.C.; LORENZI, H. Botânica sistemática: guia ilustrado para identificação das famílias de Angiosperma da flora brasileira, baseado em APG II. Nova Odessa: Instituto Plantarum, 2005.

SPRENT, J.I.; GEOGHEGAN, I.E.; WHITTY, P.W.; JAMES, E.K. Natural abundance of N-15 and C-13 in nodulated legumes and other plants in the Cerrado and neighbouring regions of Brazil. Oecologia, v.105, p.440-446, 1996.

STATSOFT. Statistica 6.0, 2004. Available at http:// www.statsoft.com. Accessed 10 Oct., 2005.

VIEIRA, M.G.L.; MORAES, J.L.; BERTONI, J.E.A.; MARTINS, F.R.; ZANDARIN, M.A. Composição florística e estrutura fitossociológica da vegetação arbórea do Parque Estadual de Vassununga, Santa Rita do Passa Quatro (S.P.). II. Gleba Capetinga Oeste. Revista Instituto Florestal, v.1, p.135-159, 1989.

VITOUSEK, P.M.; CASSMAN, K.; CLEVELAND, C.; CREWS, T.; FIELD, C.B.; GRIMM, N.B.; HOWARTH, R.W.; MARINO, R.; MARTINELLI, L.A.; RASTETTER, E.B.; SPRENT, J.I. Towards an ecological understanding of biological nitrogen fixation. Biogeochemistry, v.57, p.1-45, 2002.

WALCROFT, A.S.; SILVESTER, W.B.; WHITEHEAD, D.; KELLIHER, F.M. Seasonal changes in stable carbon isotope ratios within annual rings of Pinus radiata reflect environmental regulation of growth processes. Australian Journal of Plant Physiology, v.24, p.57-68, 1997

Received November 22, 2007

Accepted December 12, 2008 